\title{
Berlinale 2005: Special Report
}

\author{
By Ron Holloway \\ Spring 2005 Issue of KINEMA
}

A FESTIVAL of surprises and discoveries, the fourth under the aegis of Dieter Kosslick, the 55th Berlinale (10-20 February 2005) set a new attendance record - 400,000 visitors, 180,000 sold tickets - and welcomed 17,000 accredited guests from 120 countries, including 1,000 more trade passes for the European Film Market (a 30\% increase). One hopes, however, that weather conditions will be better next year than experienced this time around - following a mild winter, snow and rain arrived with a bang just after the festival opened, a misfortune that led to dampened spirits and less merriment on the red carpet before the Berlinale Palast for the gala screenings. But this didn't prevent scores of cineastes parading to the Gropius-Bau for the allembracing Stanley Kubrick Retrospective and Exhibition Tribute. After all, since the theme of this year's Berlinale Retrospective was titled "Production Design + Film," no great master of modern cinema merited the tribute more than Stanley Kubrick.

Asked by the press "what was new" at the $55^{\text {th }}$ Berlinale, Dieter Kosslick replied with an impish grin: "the films!" Then added: "The festival's comprehensive overhaul is about to come to an end." He cited the broad audience acceptance for the Perspektive Deutsches Kino, Talent Campus, youth-oriented "14plus" section in the Children's Film Festival, and the newly launched World Cinema Fund (to foster coproductions in financially hindered countries), all inaugurated under his current supervision. Then he added: "Now we are focusing on the forthcoming changes in the European Film Market." Next year, when the EFM moves over to its new domicile in the Gropius-Bau, a splendid exhibition building but a short five-minute walk away from the festival's Potsdamer Platz headquarters, a push will be made to anchor the EFM permanently as one of the three major film trade shows: Berlin in February, Cannes (MIF) in May, and the Los Angeles / American Film Market (AFM) in November.

According to some media reports, the change of dates for the Academy Award ceremonies (from the end of March to the end of February) may have hindered Hollywood attendance at the Berlinale, depending of course on whether or not a star actor or director had to stay at home to promote a film nominated for an Oscar at the same time as said film was competing for a Golden Bear. Be that as it may, the scarcity of Hollywood personalities present at the Berlinale led Dieter Kosslick to quip: "Maybe we should move the festival dates to January!" Another related flap was the sudden cancellation of an American out-of-competition entry from the official program - Chris Terrio's Heights, starring Glenn Close - to be replaced by director-cameraman Lajos Koltai's Fateless (Hungary-Germany-UK). It turned out to be a major plus for the festival, however. For not only is this autobiographical film about a Holocaust survivor based on the novel that eventually won Hungarian writer Imre Kertész a Nobel Prize for Literature in 2002, but also because the 75-year-old Kertész wrote the screenplay for this large-scale cross-European production from his base in Berlin. Indeed, Fateless was the appropriate Berlinale entry to welcome the new Central European members to the enlarged EU.

Last year, the Berlinale had opened its doors wide to Asian cinema. This year, the focus was on Africa. Regis Wargnier's Man to Man (France-UK-South Africa), a fantasy epic set in Central Africa and London in 1870 about scientists mistaking pygmies as the missing link between apes and the humans, opened the festival, followed by two films on the Rwanda genocide, Raoul Peck's Sometimes in April (USA-Rwanda) and Terry George's Hotel Rwanda (UK-South Africa-USA-Italy), and Mark Dornford-May's U-Carmen eKhayelitsha (Carmen in Khayelitsha), Bizet's popular opera adapted to a South African milieu with the lyrics translated to Xhosa township dialect. To the surprise of many, Carmen in Khayelitsha was awarded the Golden Bear, the first time in the history of the Berlinale that an African film was so honoured. As refreshingly original as this screen adaptation of an ensemble stage production set in a Cape Town township is, the better African entry was Terry George's Hotel Rwanda, nominated for three Academy Awards. The latter film, however, was running out-of-competition due to its screening last autumn at the Toronto film festival, a FIAPF-recognized event. The presence at the Berlinale of actor Don Cheadle and actress Sophie Okonedo, both nominated for Oscars, brought a standing ovation. Cheadle plays a Kigali hotelier, who risked his own life to save over a 
thousand other lives during the Rwanda genocide. As for the equally strong Sometimes in April, directed by Haitian-born Raoul Peck, who had graduated from the Berlin Film and Television Academy and had also served for a time (1995-97) as Haiti's Minister of Culture, it draws its immediacy from being shot on original Rwanda locations.

Completely overlooked for a major award was a film on nearly everyone's lips: Hany Abu-Assad's Paradise Now (Netherlands-Germany-France). Awarded the Blue Angel Prize for Best European Film, it is anything but European in theme and location. Set in the West Bank and partially filmed in Nablus, Paradise Now is directed by a Palestinian who lives in the Netherlands and tells the story of two Palestinian youths, friends from childhood, who mutually agree to be recruited for a suicide-bomber mission in Tel Aviv. Abu-Assad, whose previous feature film, Rana's Wedding (2002), was set in the divided city of Jerusalem, has taken the pulse of the times as few other directors in the Middle East by carving fiction films out of penetrating documentary material: "When the abnormality of barriers and occupation becomes an everyday reality, normal things turn into fiction," he said in an interview. "This is life in Palestine now. I want to challenge it through cinema." Although an emotionally weighed film and intelligently formulated film, the test will come, confirmed Hany Abu-Assad, when Paradise Now is screened in Palestine and the United States.

Two Asian films were also the talk of the festival. Gu Changwei's Kong Que (Peacock, China), a family film set in a Chinese provincial town between 1977 and 1984, is the first feature film by a renown Chinese cameraman for such name directors as Zhang Yimou (Red Sorghum), Chen Kaige (Farewell, My Concubine), and Robert Altman (The Gingerbread Man). Awarded the runner-up Silver Bear - the Grand Jury Prize Peacock pulls no punches in sketching the bitter trials and disappointments of a girl and boy, whose parents favour an oversize idiot son because he is the first-born. Despite its running time of two-hours-plus, Peacock is a film that crawls under the skin from the first sequence and never lets go. Indeed, the polished ensemble acting and surprising twists in the story certify Gu Changwei as a director to keep a close eye on in the future.

Malaysian-born, Taiwan-based director Tsai Ming-liang is hardly a newcomer to the Berlinale and the international festival scene. His The River (1996) was awarded a Silver Bear (Special Jury Prize) and the FIPRESCI Prize at the Berlinale. Returning to Berlin with Tian bian yi duo yun (The Wayward Cloud, Taiwan-China-France), the film was awarded a Silver Bear for Individual Artistic Contribution and the FIPRESCI Prize. With but six feature films to his credit, Tsai Ming-liang ranks as one of Asia's leading auteur directors. Significantly, Tsai found his screen alter ego in actor Lee Kang-sheng, who has subsequently appeared in all this films to date - much as Jean-Pierre Léaud served as surrogate for François Truffaut. In The Wayward Cloud Tsai picks up where he left off in What Time Is It Over There? (2001), with Lee Kangsheng, the former watch-salesman on the street before a Taipei railway station, meeting Cheng Shiang-chyi, on her return home from Paris. The rest of this elusive story is a descent into the hell of the Taiwan porno industry, interspersed with musical videos that, if nothing else, offer relief from the heavy stuff that cuts to the very edge of artistic license.

Unfortunately, Alexander Sokurov's outstanding artistic achievement, Solnce (The Sun, Russia-Italy-FranceSwitzerland), was overlooked for award citations. The latest in Sokurov's continuing portraits of historical figures - following Hitler in Moloch (1999) and Lenin in Taurus (2000) - the focus this time is on Emperor Hirohito, the "sun" (or the 124th descendant of the sun goddess Amaterasu), who addressed his nation in August of 1945 to cease fighting and acquiesce to the American Occupation. The performance of Issey Ogata as Hirohito, depicting a man fumbling for a place as human being in a world crumbling about him, well deserved the Silver Bear for Best Actor.

German entries continue to hold their own in a festival designed to promote the best of national film production. Marc Rothemund's Sophie Scholl - Die letzten Tage (Sophie Scholl - The Last Days) was awarded the Silver Bear for Best Director and the Silver Bear to Julia Jentsch for Best actress. Jentsch well deserved the honour, as the young stage actress gives a moving performance as the conscience of the "White Rose" anti-Hitler conspiracy group caught at the University of München in the 1943, interrogated and brought to trial, and then executed by guillotine. Christian Petzold's Gespenster (Ghosts) comes across as a coda in his highly acclaimed trilogy on conscience and morality: Die innere Sicherheit (The State I Am In, 2000), about a terrorist family still on the run; Toter Mann (Dead Man, 2001), about a woman's pained 
quest to avenge the murder of her sister; and Wolfsburg (2003), about a hit-and-run driver who kills a boy on a highway and cannot run away from his conscience no matter how hard he tries. In Ghosts Petzold casts Julia Hummer, the teenaged daughter in The State I Am In, as a shy orphaned girl who roams the Berlin Tiergarten (right next to the Berlinale headquarters on Potsdamer Platz) with another vagabond (Sabine Timoteo) who has even less scruples on how to survive than she does. The twist comes when a visiting French woman from Paris, who has psychological problems of her own, mistakes the orphaned girl for her daughter, who had been kidnapped at three years of age. Ghosts, a finely crafted film, takes on depth and meaning only in relation to the films that went before it.

Hannes Stöhr's One Day in Europe, the third German film in competition, is the director's second feature, following on the heels of his successful debut in the Panorama a couple years ago with Berlin Is in Germany (2001). A director with a gift for tongue-in-cheek nonchalance, Stöhr has broadened his focus to take in all of Europe with a similar tale that takes place on the same day in Moscow, Istanbul, Berlin, and Santiago de Compostela. Each time, a robbery takes place, whether actual or faked or both. Each time, the ensuing chase is linked to the TV coverage of the final soccer match in the European Champions League, Galatasaray Istanbul against Deportivo La Caruña in Moscow!

Asian cinema from the Far East has become the backbone of the International Forum of New Cinema. This year being no exception, the critical nod went to Korean films in the program. Korean master Im Kwontaek was honoured with a Berlinale Workshop that focused on three of his films: Jokbo - The Genealogy (1978), Gilsoddeum (1985), and Chukje - Festival (1996). The Netpac (Network for Promotion of Asian Cinema) Jury awarded Lee Yoon-ki's Yeoja, Jeong-hae (This Charming Girl), based on a short story and bolstered by a remarkable performance by Kim Ji-soo in the title role (the literal translation of the title is "A Woman, Jeong-hae). An attractive but timid young lady, who works in a post-office, Jeong-hae is unable to communicate her feelings to others, nor is "this charming girl" even willing to enter upon any relationship that might involve commitment. It is only at the end that the secret of her past with its painful memories comes to light in bits and pieces.

Two remarkable Chinese films in the Forum were also singled out for awards. The documentary Yan mo (Before the Flood) by Yan Yu and Li Yifan, a first film for both, was voted the prestigious Wolfgang Staudte Prize by an independent jury. Before the Flood is not just a chronicle of the building of the Three Gorges Dam on the Yangtze River, which is expected to be constructed in 2009. When the project is completed, it will dislocated thousands of people, cover hundreds and villages, leave some historical treasures and artifacts forever under water, and require relocation of come town - particularly Fengjie, the "poet's town." To the filmmakers' credit, they leaned toward showing teaming life along the river pretty much as it is in all its coarse and even brutal aspects, without adding much extra verbal or visual commentary. In a press statement the filmmakers went so far as to underscore their changing perception of the task before them: "Our fear grew with each failure to find and capture on-camera examples of human dignity before the flood."

On the surface, Liu Jiayin's Niu Pi (Oxhide, China), awarded both the Caligari Prize and a FIPRESCI Prize, seems on the surface to be little more than an autobiographical video tract about herself and her family. Running at nearly two hours, Oxhide refers to the family business of making handmade leather bags, a precarious venture that grows more difficult as the father grows older and debts accumulate. "It's my family through my eyes: narrow, depressive, dim and warm. No other people appear in the film except the three of us. Twenty-three scenes of the family's daily life make up the movie." A student at the Beijing Film Academy majoring in screenwriting., Liu Jiayin signals in Oxhide the presence of a new movement in independent filmmaking.

By the same token, Lost and Found, programmed as the opening film in the Forum, pays tribute to the progress made at the Berlinale Talent Campus over the past year. A compilation of six short films by directors from Central and Eastern Europe, the entire series fits together like a mosaic of life-and-times in the "new Europe" under the theme of "generations." An immediate hit with the audience, Lost and Found owes a vote of thanks to Icon Film in Cologne for pairing both directors and films to the general theme of the generation gap: Nadejda Koseva's The Ritual (Bulgaria), Cristian Mungiu's Turkey-Girl (Romania), Jasmila Zbanich's Birthday (Bosnia-Herzegovina), Kornel Mundruzco's Shortlasting Silence (Hungary), Stefan Arsenijevic's Fabulous Vera (Serbia \& Montenegro), and Mait Laas's animation links titled Gene+ratio 
(Estonia). Scheduled to make the rounds of international film festivals, Lost and Found may well become this year's official Berlinale calling-card abroad.

\section{References}

AWARDS

INTERNATIONAL JURY

Golden Bear

U-Carmen eKhayelitsha (Carmen in Khayelitsha, South Africa),

Mark Dornford-May

Silver Bear, Grand Jury Prize

Kong que (Peacock, China)

Gu Changwei

Silver Bear, Best Director

Marc Rothemund

Sophie Scholl - Die letzten Tage (Sophie Scholl - The Last Days, Germany)

Silver Bear, Best Actress

Julia Jentsch

Sophie Scholl - Die letzten Tage (Sophie Scholl - The Last Days, Germany)

dir Marc Rothemund

Silver Bear, Best Actor

Lou Taylor Pucci

Thumbsucker (USA)

dir Mike Mills

Silver Bear, Individual Artistic Contribution

Tsai Ming-liang, Tian bian yi duo yun (The Wayward Cloud, Taiwan-China-France)

Silver Bear, Best Film Music

Alexandre Desplat, De battre mon coeur s'est arrêté (The Beat That My Heart Skipped, France)

Jacques Audiard

AGICOA Blue Angel Prize, Best European Film

Paradise Now (Netherlands-Germany-France)

Hany Abu-Assad

Alfred Bauer Prize, for Particular Innovation

Tian bian yi duo yun (The Wayward Cloud, Taiwan-China-France), Tsai Ming-liang

Golden Bear, Short Film

Milk (UK)

Peter Mackie Burns

Silver Bear, Short Film (ex aequo)

The Intervention (USA)

Jay Duplass

Jam Session (Germany)

Izabela Plucinska

OTHER AWARDS

FIPRESCI (International Critics) Jury

Competition: Tian bian yi duo yun (The Wayward Cloud, Taiwan-China-France)

Tsai Ming-liang 
Panorama: Massaker (Massacre, Germany)

Documentary, Monica Borgmann, Lokman Slim, Hermann Theissen

Forum: Niu Pi (Oxhide, China), Liu Jiayin

Ecumenical Jury

Sophie Scholl - Die letzten Tage (Sophie Scholl - The Last Days, Germany)

Marc Rothemund

Amnesty International Film Prize

Paradise Now (Netherlands-Germany-France)

Hany Abu-Assad

Prize of Guild of German Art House Cinemas

Asylum (USA-Ireland)

David Mackenzie

Peace Film Prize

Lakposhtha ham parvaz mikonand (Turtles Can Fly, Iran-Iraq),

Bahman Ghobadi

Wolfgang Staudte Prize - Forum

Yan mo (Before the Flood, China), Yan Yu, Li Yifan

NETPAC (Network for Promotion of Asian Cinema) Prize - Forum

Yeoja, Jeong-hae (This Charming Girl, Korea), Lee Yoon-ki

Caligari Prize - Forum

Niu Pi (Oxhide, China), Liu Jiayin

Teddy Awards - Panorama

Best Feature Film

Un ano sin amor (Argentina), Anahi Berneri

Best Documentary

Katzenball (Switzerland), Veronika Minder

Panorama Audience Award

Va, vis et deviens (Live and Become, France-Israel)

Radu Mihaileanu

Crystal Bear- Best Children's Film

Bluebird (Netherlands),

Mijke de Jong

Crystal Bear - Best Youth Film - 14plus

Voces inocentes (Mexico),

Luis Mandoki

\section{Author Information}

Ron HOLLOWAY (1933-2009) was an American critic, film historian, filmmaker and correspondent who adopted Europe as his home in the early fifties and spent much of his life in Berlin. He was an expert on the study of German cinema and against all odds produced, with his wife Dorothea, the journal German Film, keeping us up-to-date with the work of directors, producers and writers and the showing of German films around the world.

In 2007, Ron Holloway and his wife were awarded the Berlinale Camera Award. Ron also received the Bundesverdienstkreuz (German Cross of Merit), Polish Rings, Cannes Gold Medaille, the American Cinema 
Foundation Award, the Diploma for Support of Russian Cinema and an honorary award from the German Film Critics' Association.

Ron was also a valued contributor to Kinema for the past fifteen years. 